\title{
Modelling soil moisture at SMOS scale by use of a SVAT model over the Valencia Anchor Station
}

\author{
S. Juglea ${ }^{1}$, Y. Kerr ${ }^{1}$, A. Mialon ${ }^{1}$, J.-P. Wigneron ${ }^{2}$, E. Lopez-Baeza ${ }^{3}$, A. Cano ${ }^{3}$, A. Albitar ${ }^{1}$, C. Millan-Scheiding ${ }^{3,4}$, \\ M. Carmen Antolin ${ }^{4}$, and S. Delwart ${ }^{5}$ \\ ${ }^{1}$ Centre d'Études Spatiales de la BIOsphère, UMR 5126 (CNRS, CNES, IRD, UPS), Toulouse, France \\ ${ }^{2}$ Ecologie fonctionnelle et PHYSique de l'Environnement (INRA/EPHYSE), Bordeaux, France \\ ${ }^{3}$ Universitat de Valencia, Departament de Termodinamica i Fisica de la Terra, Valencia, Spain \\ ${ }^{4}$ Center for Desertification Research (CIDE), Department of Territorial Planning, Valencia, Spain \\ ${ }^{5}$ European Space Research and Technology Centre (ESA/ESTEC), Noordwijk, The Netherlands
}

Received: 21 December 2009 - Published in Hydrol. Earth Syst. Sci. Discuss.: 27 January 2010

Revised: 26 April 2010 - Accepted: 19 May 2010 - Published: 28 May 2010

\begin{abstract}
The main goal of the SMOS (Soil Moisture and Ocean Salinity) mission is to deliver global fields of surface soil moisture and sea surface salinity using L-band $(1.4 \mathrm{GHz})$ radiometry. Within the context of the Science preparation for SMOS, the Valencia Anchor Station (VAS) experimental site, in Spain, was chosen to be one of the main test sites in Europe for Calibration/Validation (Cal/Val) activities. In this framework, the paper presents an approach consisting in accurately simulating a whole SMOS pixel by representing the spatial and temporal heterogeneity of the soil moisture fields over the wide VAS surface $\left(50 \times 50 \mathrm{~km}^{2}\right)$. Ground and meteorological measurements over the area are used as the input of a Soil-Vegetation-Atmosphere-Transfer (SVAT) model, SURFEX (Externalized Surface) - module ISBA (Interactions between Soil-Biosphere-Atmosphere) to simulate the spatial and temporal distribution of surface soil moisture. The calibration as well as the validation of the ISBA model are performed using in situ soil moisture measurements. It is shown that a good consistency is reached when point comparisons between simulated and in situ soil moisture measurements are made.

Actually, an important challenge in remote sensing approaches concerns product validation. In order to obtain an representative soil moisture mapping over the Valencia Anchor Station $\left(50 \times 50 \mathrm{~km}^{2}\right.$ area $)$, a spatialization method is
\end{abstract}

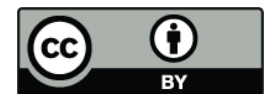

Correspondence to: S. Juglea (silvia.juglea@ cesbio.cnes.fr) applied. For verification, a comparison between the simulated spatialized soil moisture and remote sensing data from the Advanced Microwave Scanning Radiometer on Earth observing System (AMSR-E) and from the European Remote Sensing Satellites (ERS-SCAT) is performed. Despite the fact that AMSR-E surface soil moisture product is not reproducing accurately the absolute values, it provides trustworthy information on surface soil moisture temporal variability. However, during the vegetation growing season the signal is perturbed. By using the polarization ratio a better agreement is obtained. ERS-SCAT soil moisture products are also used to be compared with the simulated spatialized soil moisture. However, the lack of soil moisture data from the ERS-SCAT sensor over the area (45 observations for one year) prevented capturing the soil moisture variability.

\section{Introduction}

Soil moisture is a key variable controlling the exchanges of water and energy at the surface/atmosphere interface (Betts et al., 1996; Entekhabi et al., 1996). It is highly variable both spatially and temporally as the result of the spatial heterogeneity of soil and vegetation properties, topography, land cover, rainfall and evapo-transpiration (Bosch et al., 2006; Entekhabi and Rodrigues-Iturbe, 1994). Observing the spatial distribution of soil moisture at the catchment scale is a

Published by Copernicus Publications on behalf of the European Geosciences Union. 
difficult task requiring intensive field instrumentation for accurate spatial and temporal representation.

Nowadays, remote sensing technology has matured to the point that surface soil moisture can be estimated at global scale from space (Wigneron et al., 2003; Wagner et al., 2006). Microwave remote sensing at low frequencies have been found to produce the best results (Kerr, 2007; Wagner et al., 2006; Njoku and Entekhabi, 1996; Jones et al., 2004). In spite of the importance of soil moisture observations, the instruments that have been or are currently operating are not adapted to soil moisture monitoring. Nevertheless, there are a number of soil moisture products available from different sensors. The Advanced Microwave Scanning Radiometer for the Earth Observing System (AMSR-E) (Njoku et al., 2003) on board the National Aeronautics and Space Administration's (NASA) Aqua satellite and the scatterometers (SCAT) on board the European Remote Sensing Satellites 1 and 2 (ERS-1 and ERS-2) (Wagner et al., 1999a) provide soil moisture products. Both instruments use frequencies above $5 \mathrm{GHz}$.

The SMOS (Soil Moisture and Ocean Salinity) (Kerr et al., 2001) mission was designed to measure soil moisture over continental surfaces as well as ocean salinity using a low microwave frequency - L-band $(1.4 \mathrm{GHz})$. At this frequency, microwave observations are sensitive to soil moisture through the effects of moisture (water) on the dielectric constant and hence on the emissivity of the soil. The soil emission is integrated over a soil depth of a few centimeters, giving a more representative measurement of soil moisture conditions over this layer. Consequently, the SMOS mission benchmark is to provide global maps of soil moisture with an accuracy better than $0.04 \mathrm{~m}^{3} / \mathrm{m}^{3}$ (Kerr et al., 2001). SMOS will achieve a maximum spatial resolution of $50 \mathrm{~km}$ over land ( $43 \mathrm{~km}$ on average over the field of view), providing multi-angular dual polarized (or fully polarized) brightness temperatures over the globe (Kerr et al., 2001). Launched in November 2009, SMOS will deliver, for the first time, global surface soil moisture measurement twice a day (06:00 a.m. and 06:00 p.m. LT - local time) in less than 3 days.

L-band passive microwave radiometry is a very useful tool for soil moisture monitoring, allowing nearly all weather observation and surface vegetation cover information. Numerous field experiments using ground based and airborne Lband observations indicated a soil moisture retrieval capability of better than $0.04 \mathrm{~m}^{3} / \mathrm{m}^{3}$ accuracy (Wang et al., 1990a; Schmugge et al., 1992; Jackson et al., 1995, 1999). In this context, the strategy adapted by ESA for its Soil Moisture and Ocean Salinity mission was to develop specific land product validation activities over well equipped monitoring sites. The Valencia Anchor Station (Lopez-Baeza et al., 2005a), in eastern Spain, and the Upper Danube Catchment (Delwart et al., 2007), in southern Germany, are chosen as the two main test sites in Europe for the SMOS Calibration/Validation (Cal/Val) activities. This article will focus over the Valencia Anchor Station site which is a large reference area, equipped with ground soil moisture probes and fully characterized so as to contribute to SMOS land product validation.

Several papers evaluated the soil moisture remote sensing products (Wagner et al., 2007; Albergel et al., 2009; Draper et al., 2009; Rüdiger et al., 2009; Gruhier et al., 2010). Draper et al. (2009) provided a comparison of four soil moisture products all based on AMSR-E sensor over a temperate climate in Australia during 2006. Rüdiger et al. (2009) showed a comparison of several remotely sensed surface soil moisture products and one simulation (land surface model predictions) over the mainland of France from 2003 to 2005, in addition to a ground measurement comparison. Gruhier et al. (2010) provided an inter-comparison and evaluation of five products derived from different active and passive microwaves sensors using local ground station measurements from three different ground sites over a Sahelian area (located in the Gourma-Mali region) during two consecutive years (2005-2006).

Validating soil moisture products is a challenge and up to now, in most cases, papers describe how to relate one point measurement, or a value derived from a sparse network to a satellite product.

In the framework of SMOS Cal/Val activities, it was decided to select a set of areas scattered around the globe and representative of different types of ecoclimates. These sites are to deliver, continuously, a value representative of a whole pixel which can be compared to a satellite product at any overpass time for Cal/Val purposes. To achieve this goal it is necessary to characterise and monitor an area slightly larger than the actual pixel ( $3 \mathrm{~dB}$ footprint) in terms of brightness temperature, so that it is possible to convolute the antenna pattern on it. To acquire such a large field of soil moisture, ground measurements are not tractable so we rely on a limited set of ground sites and spatialize the soil moisture information with use of a SVAT - ISBA (Interactions between Soil-Biosphere-Atmosphere; Noilhan and Planton, 1989; Noilhan and Mahfouf, 1996) coupled to a good set of forcings and a very good knowledge of soil types and land use. Once the soil moisture fields are known, it is possible to compute satellite level brightness temperatures (to check calibration for instance) or to compare to satellite products. As the model runs with a reasonably fine time step we can always have values at the time of overpass. To check the validity of the approach we did a test with existing sensors (AMSR-E, ERS-SCAT). The paper describes how such approach is validated over one such site, the Valencia Anchor Station (VAS). The idea is then to extend the approach on several other sites (arid, temperate, boreal etc.) as, such an approach being exhaustive, it can only be applied to a limited set of sites. 


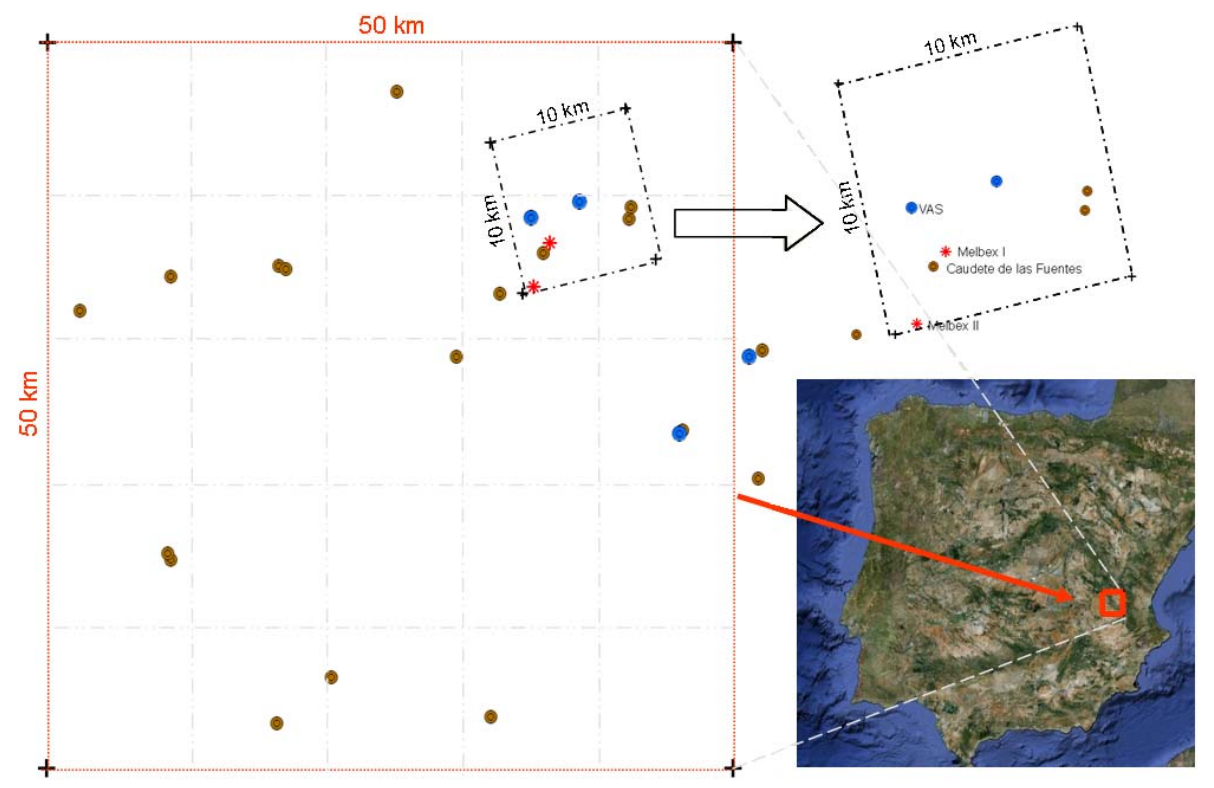

Fig. 1. Location and distribution of the meteorological stations over the $50 \times 50 \mathrm{~km}^{2}$ VAS area.

\section{Valencia Anchor Station - experimental domain and data}

The Valencia Anchor Station (VAS) site was established in December 2001 by the University of Valencia (see http: //www.uv.es/anchors and http://www.uv.es/elopez) with the main objective of characterizing a large-scale reference $\mathrm{Cal} / \mathrm{Val}$ area specifically dedicated to the validation of low spatial resolution Earth Observation data products. It is located in Spain close to the town of Caudete de las Fuentes $\left(39^{\circ} 33^{\prime} 32^{\prime \prime} \mathrm{N}, 1^{\circ} 16^{\prime} 37^{\prime \prime} \mathrm{W}\right)$, at about $80 \mathrm{~km}$ West of the city of Valencia (Fig. 1).

\subsection{Characteristics of the area}

The Valencia Anchor Station test site represents a reasonably homogeneous and mostly flat area of about $50 \times 50 \mathrm{~km}^{2}$ (Figs. 2 and 3). The main cover type is vineyards, about 56\%, followed by trees, shrubs, forest, industrial and urban. Beside the vineyard growing season, the area remains mostly under bare soil conditions. In spite of its relatively flat topography, the small altitude variations of the region clearly influence climate. It oscillates between semiarid in the areas of the towns of Utiel and Caudete de las Fuentes and dry-sub-humid towards Villagordo del Cabriel (about $16 \mathrm{~km}$ from Caudete de las Fuentes). Annual mean temperatures oscillate between $12{ }^{\circ} \mathrm{C}$ at Villagordo del Cabriel and $14.2^{\circ} \mathrm{C}$ at Caudete de las Fuentes. Annual precipitation varies between $396 \mathrm{~mm}$ in Utiel and $451 \mathrm{~mm}$ of Caudete de las Fuentes and Villagordo del Cabriel. The duration of frost free periods is similar for the three town areas, from May to November. Maximum precipitations occur in spring and autumn. The spring maximum is generally in May, whereas the autumn maximum is variable, in October for Caudete de las Fuentes and Utiel, and November for Villagordo del Cabriel.

\subsection{Available data over the area}

To reproduce and compare the soil moisture fields over the VAS $50 \times 50 \mathrm{~km}^{2}$ area, in situ measurements and remotely sensed data products are used. The characteristics of these data are depicted next.

\subsubsection{In situ measurements}

Valencia Anchor Station is characterized by an extensive set of measurements at different levels (in the atmosphere and in the soil) in order to derive surface energy fluxes. Over the $50 \times 50 \mathrm{~km}^{2}$ area 22 meteorological stations are available (Table 1), 4 fully equipped and 18 rain gauges are not uniformly distributed (Fig. 1). Only the 4 fully equipped stations measures meteorological data: air temperature and humidity at screen level, atmospheric pressure, precipitation, wind speed and direction and solar and atmospheric radiation.

In the VAS area the soil texture is a parameter that depends mainly on lithology (Lopez-Baeza et al., 2008). An accurate map representing the spatial distribution of clay and sand (Millan-Scheiding et al., 2008) at $10 \mathrm{~m}$ resolution covering all the $50 \times 50 \mathrm{~km}^{2}$ area is available (Fig. 3). The division of the texture is made in 23 main classes.

Leaf area index (LAI), roughness and fraction of vegetation are accessible during short time periods. However, as the period considered in this study is from 2004 to 2008, remote sensed LAI data are used (see Sect. 2.2.2.). The historical data for the roughness and the fraction of vegetation are 


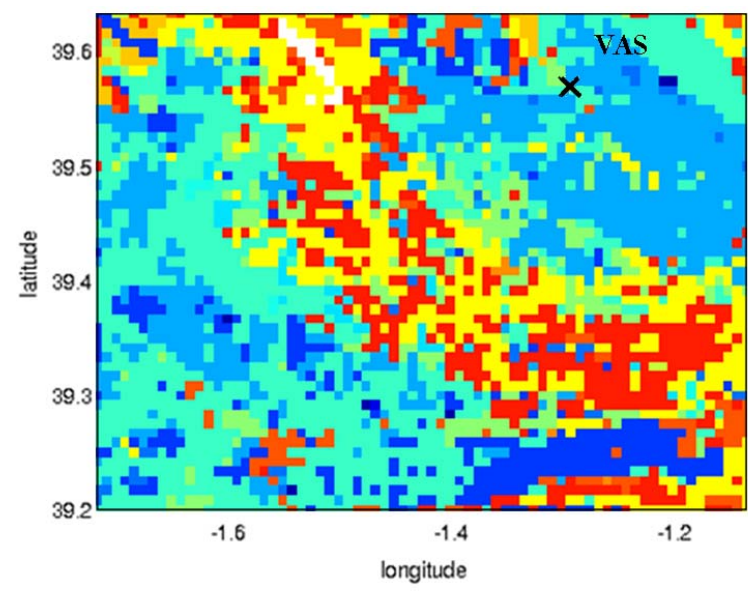

Longitude Latitude NW 1.698 W $39.684 \mathrm{~N}$ NE $1.116 \mathrm{~W} 39.676 \mathrm{~N}$ SE $1.128 \mathrm{~W} 39.225 \mathrm{~N}$ SW 1.707 W $39.233 \mathrm{~N}$
236 Sparsely vegetated areas

233 Spanish woodland

232 Mountain maquis

231 Mediterranean maquis

221 Atlantic coast (GR)

220 Mediterranean (GR)

218 Mountain mixed forest

215 Mediterranean mixed forest

210 Mountain coniferous forest

208 Mediterranean pines

199 Spanish broad-leaved forest

196 Spanish crops and woodland

181 Olive groves

180 Temperate fruit trees

179 Mediterranean fruit trees

178 Temperate vineyards

177 Mediterranean vineyards

162 Spanish crops

151 Dense urban

002 Inland waters

Fig. 2. ECOCLIMAP land cover over the $50 \times 50 \mathrm{~km}^{2}$.
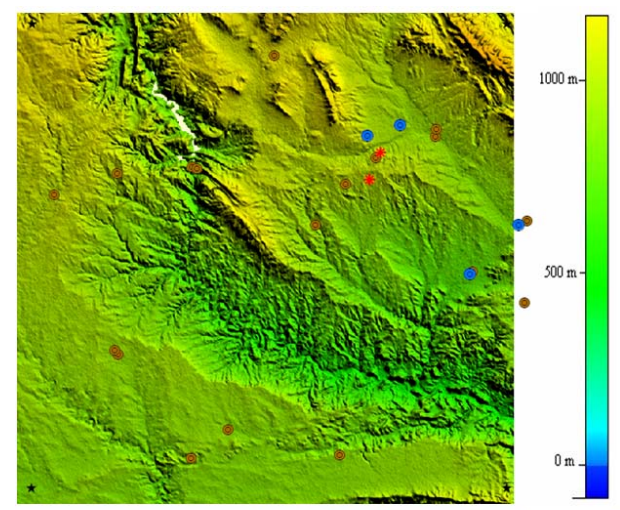

\section{Legend}

* Soil moisture

Complete meteorological station

Rain gauges

$+\quad 10 \times 10 \mathrm{~km}^{2}$ limits

$\star \quad 50 \times 50 \mathrm{~km}^{2}$ limits

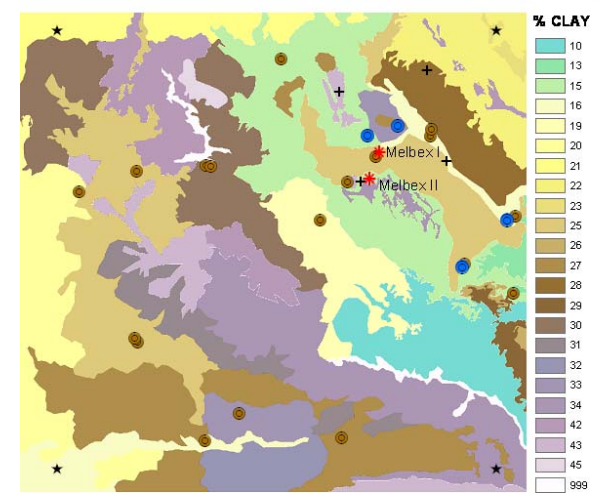

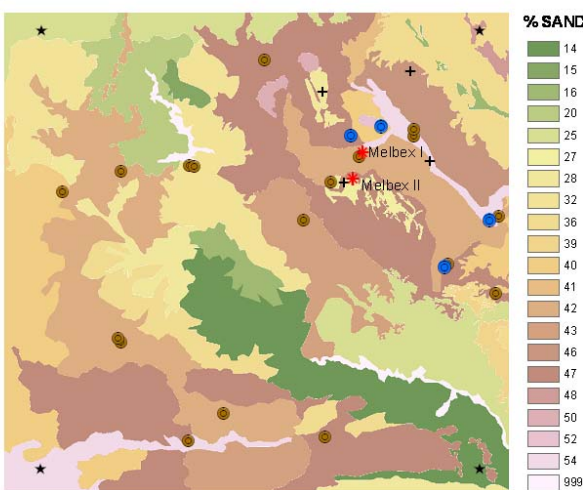

Fig. 3. Topography (up left side), clay (down left side) and sand (down right side) maps over the VAS $50 \times 50 \mathrm{~km}^{2}$ area. The soil moisture measurements sites and meteorological station/rain gauges are also represented here. 
Table 1. Coordinates of the meteorological stations located in the $50 \times 50 \mathrm{~km}^{2}$ area.

\begin{tabular}{llll}
\hline Station Name & Longitude & Latitude & Characteristics \\
\hline VAS & $1.288^{\circ} \mathrm{W}$ & $39.571^{\circ} \mathrm{N}$ & Fully equipped station \\
CASAS DE VES & $1.330^{\circ} \mathrm{W}$ & $39.262^{\circ} \mathrm{N}$ & Rain gauge \\
CASAS IBANEZ & $1.465^{\circ} \mathrm{W}$ & $39.288^{\circ} \mathrm{N}$ & Rain gauge \\
VILLAMALEA & $1.598^{\circ} \mathrm{W}$ & $39.363^{\circ} \mathrm{N}$ & Rain gauge \\
REQUENA LA PORTERA COOP. & $1.101^{\circ} \mathrm{W}$ & $39.405^{\circ} \mathrm{N}$ & Rain gauge \\
REQUENA CAMPO ARCIS & $1.165^{\circ} \mathrm{W}$ & $39.436^{\circ} \mathrm{N}$ & Rain gauge \\
DEL MORO C. H. JUCAR & $1.355^{\circ} \mathrm{W}$ & $39.484^{\circ} \mathrm{N}$ & Rain gauge \\
REQUENA & $1.096^{\circ} \mathrm{W}$ & $39.484^{\circ} \mathrm{N}$ & Rain gauge \\
CAUDETE DE LAS FUENTES & $1.317^{\circ} \mathrm{W}$ & $39.523^{\circ} \mathrm{N}$ & Rain gauge \\
MINGLANILLA & $1.595^{\circ} \mathrm{W}$ & $39.538^{\circ} \mathrm{N}$ & Rain gauge \\
PRESA DE CONTRERAS & $1.505^{\circ} \mathrm{W}$ & $39.542^{\circ} \mathrm{N}$ & Rain gauge \\
UTIEL C. H. JUCAR & $1.206^{\circ} \mathrm{W}$ & $39.568^{\circ} \mathrm{N}$ & Rain gauge \\
UTIEL & $1.205^{\circ} \mathrm{W}$ & $39.575^{\circ} \mathrm{N}$ & Rain gauge \\
UTIEL (LA CUBERA - AUTOMATICA) & $1.249^{\circ} \mathrm{W}$ & $39.580^{\circ} \mathrm{N}$ & Fully equipped station \\
CAMPORROBLES COOPERATIVA & $1.402^{\circ} \mathrm{W}$ & $39.649^{\circ} \mathrm{N}$ & Rain gauge \\
CAMPO ARCIS & $1.168^{\circ} \mathrm{W}$ & $39.433^{\circ} \mathrm{N}$ & Fully equipped station \\
CERRITO REQUENA & $1.107^{\circ} \mathrm{W}$ & $39.480^{\circ} \mathrm{N}$ & Fully equipped station \\
GRAJA DE INIESTA & $1.674^{\circ} \mathrm{W}$ & $39.516^{\circ} \mathrm{N}$ & Rain gauge \\
CONTRERAS & $1.498^{\circ} \mathrm{W}$ & $39.540^{\circ} \mathrm{N}$ & Rain gauge \\
CAUDETE DE LAS FUENTES I & $1.280^{\circ} \mathrm{W}$ & $39.547^{\circ} \mathrm{N}$ & Rain gauge \\
VILLAMALEA I & $1.602^{\circ} \mathrm{W}$ & $39.365^{\circ} \mathrm{N}$ & Rain gauge \\
CERRO & $1.512^{\circ} \mathrm{W}$ & $39.259^{\circ} \mathrm{N}$ & Rain gauge \\
\hline
\end{tabular}

obtained from ECOCLIMAP (Fig. 2), a global land use maps database at $1 \mathrm{~km}$ resolution (Masson et al., 2003).

Over the $50 \times 50 \mathrm{~km}^{2}$ area two major ground measurement campaigns took place. In order to characterize the shrubs and vineyards, in the framework of the Mediterranean Ecosystem L-Band characterization Experiment (Melbex 1 and Melbex 2), ground based L-band radiometry experiments have been developed to fully account for different soil moisture conditions and different vegetation growth development stages.

The first campaign, Melbex $1\left(39.553^{\circ} \mathrm{N}, 1.273^{\circ} \mathrm{W}\right)$, was carried out between June 2005 and January 2006 to observe the surface emission of Mediterranean shrubs (Cano et al., 2010). The soil was characterized as sandy, with a soil texture composed of $47 \%$ sand, $38 \%$ silt and $15 \%$ clay. The vegetation is well adapted to dry conditions in summer and to freeze conditions in winter. The vegetation biomass is only subject to small variations throughout the year, it does not generally grow over a meter high and its distribution is random. Soil moisture measurements were carried out for the top first $5 \mathrm{~cm}$ of the soil, at 12 points every 10 min using capacitive probes. The ground soil moisture measurements were randomly scattered over the study area by placing probes both over bare soil and under shrubs. The probes were calibrated under laboratory conditions at the end of the experiment using the same soil type in order to correctly convert the raw voltage values into volumetric soil moisture content $\left(\mathrm{m}^{3} / \mathrm{m}^{3}\right)$.

The second soil campaign, Melbex $2\left(39.526^{\circ} \mathrm{N}\right.$, $1.288^{\circ} \mathrm{W}$ ), was carried out from April 2007 to December 2007 to observe the surface emission of vineyards (Cano et al., 2008). The soil is characterized as sandy clay loam, with a texture composed of $45 \%$ sand, $29 \%$ silt and $26 \%$ clay. As in the previous experiment, soil moisture measurements were carried out at different representative points every 10 min using the same capacitive probes. In the area, the soil was ploughed at least 3 times during the growing period of vineyards.

\subsubsection{Remote sensing data}

Satellites data are used in this study. A short description of each of these data is given below.

\section{AMSR-E data}

The Advanced Microwave Scanning Radiometer (AMSR) of the Earth Observing System (EOS) is a multi-channel passive microwave instrument, launched on the Aqua satellite in May 2002. It operates in polar sun-synchronous orbit with equator crossing at 01:30 p.m. and 01:30 a.m. local solar time. Global coverage is achieved every two days or less depending on the latitude. The AMSR-E instrument 
measures dual polarized radiation at six frequencies in the range of 6.9 to $89 \mathrm{GHz}$, with an incidence angle of $55^{\circ}$. The mean spatial resolution at $6.9 \mathrm{GHz}$ is about $56 \mathrm{~km}$ with a swath width of $1445 \mathrm{~km}$.

In order to minimize the atmospheric effects and to maximize vegetation and soil penetration, the inversion algorithm for the retrieval of soil moisture was designed to use the Cband frequency in preference to the higher ones. However, due to the high level of RFI (Radio Frequency Interference) observed by AMSR-E at $6.9 \mathrm{GHz}$, the current AMSR-E soil moisture retrievals use only the $10.7 \mathrm{GHz}$ and higher frequencies (Njoku et al., 2003).

The data used in this study are from the National Snow and Ice Data Center (NSIDC) Level 3 AMSR-E dataset (Njoku, 2004). The daily averages of brightness temperature and soil moisture products are re-sampled to a global cylindrical $25 \mathrm{~km}$ Equal-Area Scalable Earth Grid (EASE-Grid) cell spacing (Njoku, 2004).

In addition to the soil moisture, the polarization ratio (PR) at $6.9 \mathrm{Ghz}$ is used and is defined as:

$\mathrm{PR}=\frac{T b_{v}-T b_{h}}{T b_{v}+T b_{h}}$

It normalizes out the surface temperature and leaves a quantity that depends primarily on soil moisture, vegetation and atmosphere (Kerr and Njoku, 1990; Njoku et al., 2003; Owe et al., 2001). At low microwave frequencies, the polarization ratio has often been used to study soil moisture and vegetation effects. Its dynamic is well related to the soil moisture variations. At increasingly large angles $\left(55^{\circ}\right.$ in this case) there is a longer observation path through the vegetation layer, causing greater attenuation of the emission from the underlying soil and reducing the sensitivity to the soil moisture (Njoku et al., 2003).

Several studies investigated the validation and evaluation of AMSR-E soil moisture product (Gruhier et al., 2008; Rüdiger et al., 2009; Draper et al., 2009). As the AMSR-E soil moisture product shows biases and very small amplitude, a normalization between $(0,1)$ is done using:

$y^{\prime}=\frac{y-y_{\min }}{y_{\max }-y_{\min }}$

where $y^{\prime}$ is the normalized curve and $y$ is the input curve (in this case $y$ is considered as the soil moisture product). Consequently, the discussion of this paper is focus on the normalized dataset.

\section{ERS-SCAT data}

The ERS (European Remote Sensing Satellites) scatterometer is an active low-resolution microwave sensor flown on the board of the ERS-1 and ERS-2 satellites. ERS-1 was launched in July 1991 followed by the identical ERS-2 in 1995. The first objective of this sensor is to measure wind over oceans, but its measurements have been shown to be highly suitable for surface soil moisture remote sensing (Magagi and Kerr, 1997; Wagner et al., 1999a). The ERS scatterometer operates at $5.3 \mathrm{GHz}$ (C-band), vertical polarization, collecting backscatter measurements over an incidence angle range from $18^{\circ}$ to $57^{\circ}$. It operates in polar sun-synchronous orbit with equator crossing times at 10:30/22:30. The spatial resolution of the ERS-SCAT footprint is about $50 \mathrm{~km}$ with a $12.5 \mathrm{~km}$ spatial sampling interval.

The surface soil moisture data are retrieved from the radar backscattering coefficients, using the change detection method suggested by Dobson and Ulaby (1976). The methodology is described by Wagner et al. (1999a,b) which takes advantage of the information provided by the dual incidence angle measurements acquired by the ERS scatterometer. The backscattering coefficients are normalized to a reference incidence angle of $40^{\circ}$. The relative soil moisture data ranging from $0 \%$ to $100 \%$ are derived by scaling the normalized backscattering coefficients between the lowest/highest values corresponding to the driest/wettest soil conditions.

\section{MODIS data}

The Moderate Resolution Imaging Spectroradiometer (MODIS; http://modis.gsfc.nasa.gov/) is an instrument on board of NASA's Terra and Aqua platforms. The MODIS LAI product is globally tiled and is projected on a sinusoidal grid which is an equivalent projection conserving the surface areas. It is at $1 \mathrm{~km}$ spatial resolution provided on a daily and 8-day basis and they are used as input to the SVAT model.

\section{METEOSAT data}

The METEOSAT radiometer is a geostationary weather satellite launched by the European Space Agency (ESA). In order to run the SVAT model and so to produce soil moisture maps, an atmospheric forcing is needed. One of the parameters of the atmospheric forcing is the shortwave radiation. As already mentioned, only 4 meteorological stations measuring shortwave radiation are available over the VAS area. For a better resolution over the entire area, the shortwave radiation flux products developed by Météo-France in the framework of the Satellite Application Facility on Land Surface Analysis (Land-SAF) are used (http://www.meteo.pt/landsaf/). The product is based on the $0.6 \mu \mathrm{m}, 0.8 \mu \mathrm{m}$ and $1.6 \mu \mathrm{m}$ channels of the Meteosat/SEVIRI instrument and is calculated and distributed in near real time.

\section{The SVAT model}

The SVAT model is used to generate, from atmospheric forcing and initial conditions, the temporal behavior of the soil 
moisture. Spatially distributed fields and forcing enable to simulate soil moisture spatial and temporal behavior and thus averaged soil moisture at any moment for the whole pixel $\left(50 \times 50 \mathrm{~km}^{2}\right)$. The model used is SURFEX (stands for surface externalisée - Le Moigne et al., 2009) and was developed at the National Center for Meteorological Research (CNRM) at Météo-France. It gathers all the developments and improvements made in surface schemes, containing four different modules: ISBA (Interactions between SoilBiosphere-Atmosphere), Sea and ocean, TEB (Town Energy Balance) and Lake. In this article only the module for the soil and vegetation - ISBA (Noilhan and Planton, 1989) is used. ISBA is a SVAT scheme which describes the exchanges of heat and water between the low-level atmosphere, the vegetation and the soil. It depends on the type of soil and of vegetation. It has been widely validated over vegetated and bare ground surfaces (Mahfouf and Noilhan, 1991; Calvet et al., 1998).

The soil module in ISBA can be run in different configurations: 2-layers, 3-layers (ISBA-2L, ISBA-3L - with forcerestored discretization) and diffusive (ISBA-DIF). New possibilities comparing with ISBA-2 or 3 layers are available by using ISBA-DIF: the computation of a vertical profile of the temperature, liquid water and ice content over as many layers as needed. This scheme has already been applied successfully over a fallow site (Boone et al., 2000) and an agricultural site (Boone et al., 1999). In order to select the most appropriate configuration, different tests are made. A significant decrease in error is obtained in the case of a diffusive scheme so for our study the ISBA-DIF model is used.

Soil water transfer (infiltration, runoff, diffusion and drainage) in SVAT's is computed by equations which attempt to characterize the soil through a set of hydrological parameters. The ISBA scheme uses the Clapp and Hornberger (1978) soil water model, which is common to a large number of surface parametrization schemes. The estimation of the diffusion of water in the soil is based on Darcy's law, where the water vertical flux is proportional to the gradient of the matric potential through the hydraulic conductivity.

$F=-k \frac{\partial}{\partial z}(\Psi+z)-D_{v} \Psi \frac{\partial \Psi}{\partial z}-K_{d}$

where $D_{v \Psi}$ is the vapor conductivity (Braud et al., 1993), $\Psi$ is the soil water matric potential $(m), K_{d}$ is an additional linear background drainage term $\left(\mathrm{ms}^{-1}\right)$ and $k$ is the hydraulic conductivity $\left(\mathrm{m} \mathrm{s}^{-1}\right)$. The hydraulic conductivity $k$ $\left(\mathrm{m} \mathrm{s}^{-1}\right)$ and the soil water matric potential $\Psi(\mathrm{m})$ are related to the liquid volumetric soil water content through (Brooks and Corey, 1966; Clapp and Hornberger, 1978):

$k=k_{\text {sat }}\left(\frac{w_{l}}{w_{\text {sat }}}\right)^{2 b+3}$
$\Psi=\Psi_{\text {sat }}\left(\frac{w_{l}}{w_{\text {sat }}}\right)^{-b}$

where $b$ is the coefficient of the water retention curve.

\subsection{SVAT configuration}

In this section, the different sensitivity studies made as well as the parametrization chosen for the soil hydraulic functions are described. The characteristics of the data used for the calibration, validation and spatialization of SVAT model are also depicted.

The atmospheric forcing, needed to run the ISBA model, is composed of: air temperature and humidity at screen level, atmospheric pressure, precipitation, wind speed and direction and solar and atmospheric radiation. ISBA can have 12 patch types to characterize land use and related vegetation parametrization. For our case study, as the vegetation on the VAS site is mainly composed of vineyards, almonds trees (groves) and shrubs, the crops case is considered.

An important aspect is the soil layer discretization that enables one to compare realistic configurations as a function of the penetration depth, between ground measurements and/or the remote sensing data. A sensitivity study was conducted in order to test the influence of different parameters. The most representative configuration was chosen with 13 layers, with different thickness, from $1 \mathrm{~cm}$ at the surface down to $1.50 \mathrm{~m}$ of depth $(1,2,3,4,5,7,9,10,30,50,80,100,150 \mathrm{~cm})$.

\subsubsection{Calibration of the SVAT}

The calibration of the SVAT model is done to be applied over the entire test site for any season/year. In order to accurately perform the SVAT model calibration, ground measurements are needed. For this purpose, ground measurements from Melbex 1 campaign are used. The period considered goes from July to December 2005. Soil moisture measurements were carried out for the top first $5 \mathrm{~cm}$ of the soil every $10 \mathrm{~min}$ using capacitive probes. The atmospheric forcing is established as follows: the precipitation events are from a rain gauge (Caudete de las Fuentes) recording data at an hourly basis; the temperature, pression, wind speed, wind direction and relative humidity are from the nearest complete meteorological station; the shortwave is a Land-SAF product and the longwave is calculated using the formulation from Brutsaert (1975). In order to reproduce the exact condition from the Melbex 1 site, the same texture is considered, $47 \%$ sand, $38 \%$ silt and $15 \%$ clay. The LAI is from MODIS and both the fraction of vegetation and the roughness are from ECOCLIMAP. The SVAT model is run on from 2004 until 2008 in a hourly basis.

The performance of the land-surface schemes and hence the soil moisture simulations are sensitive to the choice of soil hydraulic parameters (Shao and Henderson-Sellers, 1996). Most of these hydrological parameters are site dependent. They are obtained from measurements or they are prescribed. It is difficult to prescribe a value for the wilting point $\left(w_{\text {wilt }}\right)$, field capacity $\left(w_{\text {fc }}\right)$, hydraulic conductivity at saturation $\left(k_{\text {sat }}\right)$, saturated soil moisture $\left(w_{\text {sat }}\right)$, the coefficient of the water retention curve $(b)$ or for the matric 
Table 2. Equation of hydrological parameters used in default (DEFAULT ISBA (1) see Giordani, 1993; Noilhan and Lacarrère, 1995) and calibrated (CALIBRATED ISBA (2) see Cosby et al. (1984) and Boone et al., 1999) version of ISBA.

\begin{tabular}{|c|c|c|}
\hline VARIABLE & DEFAULT ISBA (1) & CALIBRATED ISBA (2) \\
\hline$b(-/-)$ & $b=13.7 * \mathrm{CLAY}+3.501$ & $\begin{array}{l}b \_ \text {mean }=3.10+0.157 * \mathrm{CLAY} * 100+(-0.003) * \mathrm{SAND}^{*} 100 \\
b \_s t \_d e v=0.92+0.049 * \mathrm{CLAY} * 100+\left(100-\mathrm{CLAY} * 100-\mathrm{SAND}^{*} 100\right) * 0.014 \\
b=b \_ \text {mean }+b \_s t \_d e v\end{array}$ \\
\hline$\Psi_{\text {sat }}(\mathrm{m})$ & $\Psi_{\mathrm{sat}}=-10^{(1.85-0.88 * \mathrm{SAND})} * 0.01$ & $\begin{array}{l}\Psi_{\text {sat_mean }}=(1.54+(-0.010) * S A N D * 100+0.006 *(100-C L A Y * 100-S A N D * 100)) \\
\Psi_{\text {sat_st_dev }}=\left(0.72+(-0.0026) *\left(100-C L A Y * 100-S_{\text {SAND }} * 100\right)+0.001 * C L A Y * 100\right) \\
\Psi_{\text {sat }}=-\left(10 \Psi_{\text {sat_mean }}-\Psi_{\text {sat_st_dev }} / 100\right)\end{array}$ \\
\hline$k_{\text {sat }}\left(\mathrm{m} \mathrm{s}^{-1}\right)$ & $k_{\text {sat }}=$ see $\left({ }^{*}\right)$ & $\begin{array}{l}k_{\text {sat_mean }}=(-0.60+0.013 * \text { SAND } * 100+(-0.0064) * \text { CLAY } * 100) \\
k_{\text {sat_st_dev }}=(0.43+0.003 *(100-\text { CLAY } * 100-S A N D * 100)+0.001 * \text { CLAY } * 100) \\
k_{\text {sat }}=10^{k_{\text {sat_mean }}-k_{\text {sat_st_dev }} *(2.54 / 360000)}\end{array}$ \\
\hline$w_{\text {sat }}\left(\mathrm{m}^{3} \mathrm{~m}^{-3}\right)$ & $w_{\mathrm{sat}}=0.001 *(-108 * \mathrm{SAND}+494.305)$ & $\begin{array}{l}w_{\text {sat_mean }}=(50.5+(-0.142) * \mathrm{SAND} * 100+(-0.037) * \mathrm{CLAY} * 100) / 100 \\
w_{\text {sat_st_dev }}=(8.23+(-0.081) * \mathrm{CLAY} * 100+(-0.007) * \mathrm{SAND} * 100) / 100 \\
w_{1 \text { sat }}=w_{\text {sat_mean }}+w_{\text {sat_st_dev }}\end{array}$ \\
\hline$w_{\text {wilt }}\left(\mathrm{m}^{3} \mathrm{~m}^{-3}\right)$ & $w_{\text {wilt }}=37.134 \mathrm{E}-3 * \mathrm{CLAY}{ }^{0.5}$ & $w_{\text {wilt }}=17.134 \mathrm{E}-3 * \mathrm{CLAY}{ }^{0.5}$ \\
\hline$w_{\mathrm{fc}}\left(\mathrm{m}^{3} \mathrm{~m}^{-3}\right)$ & $w_{\mathrm{fc}}=89.047 \mathrm{E}-3 * \mathrm{CLAY} 0.349$ & $w_{\mathrm{fc}}=89.047 \mathrm{E}-3 * \mathrm{CLAY}^{0.349}$ \\
\hline
\end{tabular}

$*: 1.0 \mathrm{e}-6 * 10\left(0.162 \mathrm{E}+01-0.582 \mathrm{E}+01 * \mathrm{CLAY}-0.907 \mathrm{E}-01 * \mathrm{SAND}+0.529 \mathrm{E}+01 * \mathrm{CLAY}^{2}+0.120 \mathrm{E}+01 * \mathrm{SAND}^{2}\right)$

potential at saturation $\left(\Psi_{\text {sat }}\right)$. To take into account the characteristics of the VAS area, the establishment of new databases for soil hydraulic parameters is necessary to improve the soil moisture simulations. The hydrological parameters of the soil ( $\left.k_{\text {sat }}, w_{\text {sat }}, b, \Psi_{\text {sat }}\right)$ are calculated using empirical equations as a function of the percentages of sand and clay. Using ISBA's default relations (Giordani, 1993; Noilhan and Lacarrère, 1995) to compute the soil parameters (see Table 2), the simulated soil moisture obtained is not in perfect accordance with the ground measurements recorded during the Melbex 1 campaign. In order to minimize this difference, a new set of equations (see Table 2) for the soil hydraulic parameters are established using Cosby et al. (1984); Boone et al. (1999). These calibrated equations are optimized inside the confidence interval defined in Cosby et al. (1984); Boone et al. (1999). Both sets of data, the one used by default by ISBA and the one from the calibrated version, are obtained from the same 11 textural classes and the same dataset. The results of the comparison between ground measurements and the simulated soil moisture using the new set of equations are given in Sect. 4.

\subsubsection{Validation of the SVAT}

In order to validate the calibration of the SVAT over another representative land use and other season/year, the Melbex 2 data are used. Carried out from April to December 2007 to observe the surface emission of vineyards, the soil moisture measurements were recorded for the first $5 \mathrm{~cm}$ of the soil every $10 \mathrm{~min}$. Due the short distance between Melbex 1 and Melbex 2 campaigns sites (about $3 \mathrm{~km}$ ), the same atmospheric forcing is used for both cases. The Caudete de las Fuentes rain gauge is situated about $3 \mathrm{~km}$ away from Melbex 2 site. However, the texture (45\% sand, $29 \%$ silt and $26 \%$ clay), the LAI (MODIS), the fraction of vegetation and the roughness (ECOCLIMAP) are specific to the Melbex 2 site. In this case also the SVAT model was run on from 2004 until 2008 in a hourly basis (spin up).

\subsubsection{SVAT distribution over the $50 \times 50 \mathrm{~km}^{2}$ area}

The distribution of soil moisture patterns throughout a catchment plays a critical role in a variety of hydrological processes. Observing the spatial distribution of soil moisture at the catchment scale is a difficult task requiring intensive field instrumentation for an accurate spatial representation. A SVAT model driven with a fine resolution of meteorological forcing and land surface data can help understanding these processes. For this purpose, a trade off between the simulation time and the needs in spatial data was found by dividing the $50 \times 50 \mathrm{~km}^{2}$ area into 25 grid surfaces of $10 \times 10 \mathrm{~km}^{2}$ each (see Fig. 1). The available data sets over the area are in different formats and resolution so they had to be transformed so as to fit the gridded area. The way these scaling are performed is depicted in the next section.

\subsection{Spatialization method}

The $50 \times 50 \mathrm{~km}^{2}$ is divided into 25 areas of $10 \times 10 \mathrm{~km}^{2}$ each so as to better reproduce the high temporal and spatial heterogeneity of soil moisture fields over the entire VAS area. In situ measurement (soil moisture), detailed knowledge of the environment (land use, texture) and meteorological stations 
are used to characterize VAS. The format and the use of these data as an input to the SVAT model is presented in this section. The spatialized soil moisture obtained is compared with remote sensing data from AMSR-E and ERS-SCAT. To reduce the scaling issue, these remote sensing products are transformed as depicted next.

\subsubsection{Interpolation}

The atmospheric forcing is used as an input to the SVAT model to obtain the surface soil moisture. According to the dataset, in the 4 fully equipped meteorological stations located into the VAS $50 \times 50 \mathrm{~km}^{2}$ area, the measured data are registered on a 30/60 min basis. In addition, among the rain gauges, some of them are recording the weather information daily. In order to run the SVAT models with a suitable temporal resolution, standard diurnal cycles are reconstructed from the daily data.

Figure 1 presents the spatial distribution of the available meteorological station over the VAS $50 \times 50 \mathrm{~km}^{2}$ area. An irregular distribution of the stations can be noticed, especially in the center of the area where there is no data. So as to obtain a good representation of soil moisture over the entire area, an interpolation of all the available meteorological stations is necessary. In order to choose the most appropriate interpolation method between the inverse distance weighted (IDW) method and kriging, tests are done for different dates and for different meteorological stations/rain gauges. By doing a cross-validation analysis in general both techniques give the same behavior. The differences between the use of IDW or kriging are not significant so the choice of a sophisticated technique like the kriging is not justified. Moreover, the limited number of meteorological station/rain gauges as well as their location over the wide VAS area, was an additional reason for selecting the IDW method as the interpolation technique.

Inverse distance weighted methods are based on the assumption that the interpolated surface should be influenced mostly by the nearby points and less by the more distanced points. A general form of finding an interpolated value $u$ for a given point $x$ is an interpolated function:

$u(x)=\frac{\sum_{k=0}^{N} w_{k}(x) u_{k}}{\sum_{k=0}^{N} w_{k}(x)}$

where the weight function is:

$w_{k}(x)=\frac{1}{d\left(x, x_{k}\right)}$

defined by Shepard (1968), $x$ denotes an interpolated (arbitrary point), $x_{k}$ is the interpolated (known) point, $d$ is a given distance from the known point $x_{k}$ to the unknown point $x$ and $N$ is the total number of known points. Using IDW method, the temperature, atmospheric pressure, wind speed, wind direction and the relative humidity are interpolated over the $10 \times 10 \mathrm{~km}^{2}$ grid by using the 4 complete meteorological stations. The shortwave fluxes are extracted over the same grid from the Land-SAF radiation product while the longwave fluxes are calculated using the interpolated data and the formulation from Brutsaert (1975). For the precipitation interpolation, all the 22 stations/rain gauges are considered.

Following the interpolation, we have an optimal spatial and temporal distribution of the atmospheric forcing over the VAS $50 \times 50 \mathrm{~km}^{2}$ area.

\subsubsection{Aggregation}

The surface characteristics are also important to be considered in SVAT's input. The LAI (MODIS), the roughness and the fraction of vegetation (ECOCLIMAP) are $1 \mathrm{~km}$ resolution products. Due to their different spatial resolutions when compared to the $10 \times 10 \mathrm{~km}^{2}$ grid, these products are aggregated though a spatial mean. For the texture, as the maps available are at $10 \mathrm{~m}$ resolution, the aggregation to the $10 \times 10 \mathrm{~km}^{2}$ is done. In this case, the majority texture class is considered into the grid area.

The data obtained after spatialization thus the aggregated data used in order to simulate the spatialized soil moisture are depicted in Table 3. This allows to simulate the soil moisture over the chosen grid: in this case 25 points.

\subsubsection{Mean}

Once the soil moisture fields are known over the $10 \times 10 \mathrm{~km}^{2}$ grid, it is possible to compare to satellite products. To check both the approach presented in this paper and to validate all the aggregation techniques (several parameters are non linear but we rely on the fact that the overall variations are smooth and/or small enough to allow one to consider them as pseudo linear), we compared the spatialized soil moisture to existing products derived from either AMSR-E or from ERS-SCAT. The remote sensing products used are considered so as to correspond to the $50 \times 50 \mathrm{~km}^{2}$ area. The AMSR$\mathrm{E}$ brightness temperature and soil moisture products are resampled to a global cylindrical $25 \mathrm{~km}$ Equal-Area Scalable Earth Grid (EASE-Grid) cell spacing (Njoku, 2004). Two AMSR-E soil moisture sampled pixel are covering the VAS area. The average of these two pixels is considered to be representative for the $50 \times 50 \mathrm{~km}^{2}$ area. For the ERS-SCAT, the footprint is about $50 \mathrm{~km}$ with a $12.5 \mathrm{~km}$ spatial sampling interval. This gives 16 ERS-SCAT soil moisture products over the $50 \times 50 \mathrm{~km}^{2}$ area. In order to have a maximum temporal and spatial cover, the mean value of the 16 pixels is considered to be representative over the VAS area.

\section{Results}

An evaluation of the surface soil moisture obtained from ISBA was undertaken so as to quantify the improvement gained from the calibration. 
Table 3. Resolution and data used as input of the SVAT model in order to obtain the spatialized soil moisture.

\begin{tabular}{lll}
\hline VARIABLE & INPUT sources & OUTPUT resolution \\
\hline LAI & MODIS $-1 \mathrm{~km}$ resolution & aggregated to $10 \times 10 \mathrm{~km}^{2}$ \\
ROUGHNESS & ECOCLIMAP $-1 \mathrm{~km}$ resolution & aggregated to $10 \times 10 \mathrm{~km}^{2}$ \\
FRACTION OF VEGETATION & ECOCLIMAP $-1 \mathrm{~km}$ resolution & aggregated to $10 \times 10 \mathrm{~km}^{2}$ \\
TEXTURE & clay and sand map at $10 \mathrm{~m}$ resolution & aggregated to $10 \times 10 \mathrm{~km}^{2}$ \\
TEMPERATURE & 4 meteorological stations & interpolated at $10 \times 10 \mathrm{~km}^{2}$ \\
PRESSURE & 4 meteorological stations & interpolated at $10 \times 10 \mathrm{~km}^{2}$ \\
WIND SPEED & 4 meteorological stations & interpolated at $10 \times 10 \mathrm{~km}^{2}$ \\
WIND DIRECTION & 4 meteorological stations & interpolated at $10 \times 10 \mathrm{~km}^{2}$ \\
RELATIVE HUMIDITY & 4 meteorological stations & interpolated at $10 \times 10 \mathrm{~km}^{2}$ \\
SHORTWAVE fluxes & METEOSAT & extracted at $10 \times 10 \mathrm{~km}^{2}$ \\
LONGWAVE fluxes & calculated using interpolated atmospheric data & \\
PRECIPITATION & 22 meteorological stations & interpolated at $10 \times 10 \mathrm{~km}^{2}$
\end{tabular}

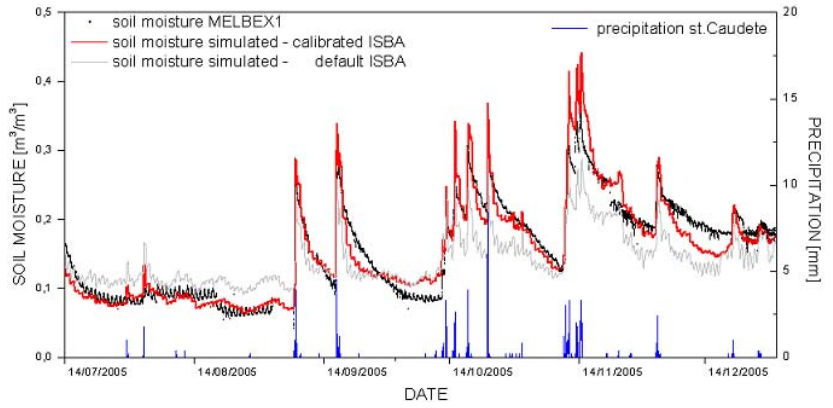

Fig. 4. Comparison between observed (black line) and simulated soil moisture using the default ISBA (clear grey line) and the calibrated ISBA (red line) at $5 \mathrm{~cm}$ depth. The precipitation corresponding to the meteorological station Caudete de las Fuentes are represented in blue.

In a first step the differences when using the default or calibrated version of ISBA are shown by comparing with in situ measurements registered during the Melbex 1 campaign. Then, the calibrated version of ISBA is tested by comparing with data from Melbex 2 campaign (different place and different period). Point-like and $10 \times 10 \mathrm{~km}^{2}$ simulations are compared to ground measurements. In a second step, the calibrated version of ISBA as well as the spatialization method described in the previous section are used to obtain a spatial distribution of soil moisture over the entire area. The validity of the method was tested and the next paragraph presents a comparison between the spatialized soil moisture and remotely sensed data. As the area was divided into 25 pseudopixels $\left(10 \times 10 \mathrm{~km}^{2} \mathrm{each}\right)$, in order to have a representative value over the entire $50 \times 50 \mathrm{~km}^{2}$, resulting values were averaged both spatially and over time. The soil moisture simulations were extracted for the time steps close to the overpass times of the satellites. The penetration depth was also taken into account, $2 \mathrm{~cm}$ for AMSR-E and for the ERS-SCAT product.

\subsection{Ground measurements versus point-like soil moisture}

\subsubsection{Calibration of ISBA model using Melbex 1 campaign}

Figure 4 compares the soil moisture from the Melbex 1 campaign and the point-like soil moisture simulated with ISBA using the parametrization described in Sect. 2.3 (default and the new set of equations). The precipitation recorded at the meteorological station Caudete de las Fuentes are represented in blue. The simulations are done for the period 2004-2008. Recorded soil moisture estimates are used as initial condition for the SVAT as well as a spin up of more than a year is done. For graphical convenience, only the period corresponding to Melbex 1 campaign (14 July-31 December 2005) is presented.

Using the initial equations, the model tended to overestimate soil moisture in the dry season (from July to September) and to underestimate soil moisture for the rest of the period. In general a good agreement between the two datasets (correlation $R^{2}=0.793-/-$, Nash efficiency Eff=0.619-/-) is observed, but the RMSE (Root Mean Squared Error) value equal to $0.042 \mathrm{~m}^{3} / \mathrm{m}^{3}$ is higher than the SMOS requirements $-0.04 \mathrm{~m}^{3} / \mathrm{m}^{3}$. In order to minimize this error, the SVAT model is calibrated (see Sect. 2.3). Table 4 presents the calculated soil hydraulic values using the default equations and the calibrated ones (Table 2).

Using the default equations (see Table 2), the SVAT model is not able to represent faithfully the dynamics of the first layer of soil during the dry season, keeping it at high soil moisture values (more than $0.10 \mathrm{~m}^{3} / \mathrm{m}^{3}$ ). In order to enable lower values of soil moisture into the dry season, the wilting point equation is modified as follows. The value obtained for the wilting point using the default equation is about $0.140 \mathrm{~m}^{3} / \mathrm{m}^{3}$, whereas the minimum observed value of soil moisture during the campaign is $0.040 \mathrm{~m}^{3} / \mathrm{m}^{3}$. This behavior 
Table 4. Soil hydraulic values for Melbex 1 site calculated using the default and the calibrated set of equations.

\begin{tabular}{lllllll}
\hline & $b(-/-)$ & $\Psi_{\text {sat }}(\mathrm{m})$ & $k_{\mathrm{sat}}\left(\mathrm{m} \mathrm{s}^{-1}\right)$ & $w_{\mathrm{sat}}\left(\mathrm{m}^{3} \mathrm{~m}^{-3}\right)$ & $w_{\text {wilt }}\left(\mathrm{m}^{3} \mathrm{~m}^{-3}\right)$ & $w_{\mathrm{fc}}\left(\mathrm{m}^{3} \mathrm{~m}^{-3}\right)$ \\
\hline DEFAULT ISBA & 5.556 & -0.172 & $1.225 \mathrm{E}-05$ & 0.444 & 0.144 & 0.230 \\
CALIBRATED ISBA & 7.519 & -0.049 & $1.502 \mathrm{E}-06$ & 0.499 & 0.066 & 0.230 \\
\hline
\end{tabular}

Table 5. Statistics obtained by comparing the in situ measurements from Melbex 1 campaign with the default/calibrated simulated soil moisture using ISBA.

\begin{tabular}{lllll}
\hline & $R^{2}(-/-)$ & $\operatorname{RMSE}\left(\mathrm{m}^{3} \mathrm{~m}^{-3}\right)$ & MEAN BIAS $\left(\mathrm{m}^{3} \mathrm{~m}^{-3}\right)$ & NASH EFFICIENCY (-/-) \\
\hline DEFAULT ISBA & 0.793 & 0.042 & 0.015 & 0.619 \\
CALIBRATED ISBA & 0.907 & 0.022 & 0.001 & 0.895 \\
\hline
\end{tabular}

was also observed by Pellarin et al. (2009), where a value of wilting point of $0.040 \mathrm{~m}^{3} / \mathrm{m}^{3}$ was used for the simulation in Niger. The default SVAT equation is modified so as to retrieve a more representative value to simulate the dry period. The default equation for volumetric water content at saturation $\left(w_{\text {sat }}\right)$ is also optimized. The goal is to reach a more representative value over a sandy soil as in Melbex 1 case (47\% sand, $38 \%$ silt and $15 \%$ clay) at least for the first centimeters of soil.

The simulated soil moisture is driven mostly by the weather patterns and especially by the precipitation. The temporal evolution of surface soil moisture has a sharp increase and exponential decline which are caused, respectively by rainfall events and consecutive drying periods. By increasing the coefficient of the retention curve and reducing the hydraulic conductivity at saturation by the use of the calibrated equations, the drainage dynamics are slowed down in order to encounter the same behavior as for the measured soil moisture.

Using the calibrated version of ISBA a significant improvement is obtained for the modelled soil moisture at the first $5 \mathrm{~cm}\left(R^{2}=0.908-/-\right.$, Eff=0.895-/- - see Table 5). A good quantitative agreement is found $\left(\mathrm{RMSE}=0.022 \mathrm{~m}^{3} / \mathrm{m}^{3}\right.$ ) between the two soil moisture data: the same variability, the same drying slope, same low levels and amplitudes. At the beginning of November a higher level of modelled surface soil moisture dynamics is observed compared with in situ data. This can be due to the high value of $w_{\text {sat }}$.

\subsubsection{Validation of ISBA new parametrization using Melbex 2 campaign}

The first step of our study was to find a parametrization of the surface model which minimizes the error compared with in situ measurements. In order to evaluate the validity of the chosen optimization, the same equations (see Table 2) as described in Sect. 2.3 are used for Melbex 2

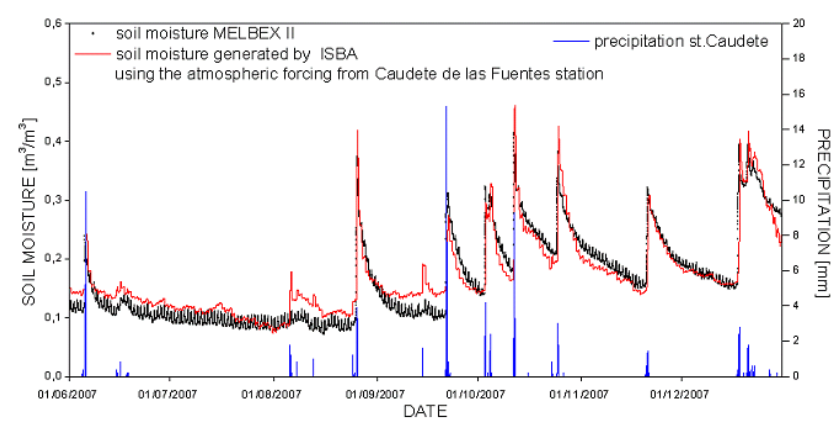

Fig. 5. Comparison between observed (black line) and simulated soil moisture using the calibrated ISBA (red line) at $5 \mathrm{~cm}$ depth. The precipitation corresponding to the meteorological station Caudete de las Fuentes are represented in blue.

area. Figure 5 presents a comparison between Melbex 2 data (in black) and simulated soil moisture (in red). A good agreement is retrieved between the two soil moisture data $\mathrm{RMSE}=0.024 \mathrm{~m}^{3} / \mathrm{m}^{3}, R^{2}=0.910-/-$. Some differences can be observed on 10 August and also on 15 September. These differences can be mostly associated to the fact that the meteorological station used is situated at almost $3 \mathrm{~km}$ from the place were the campaign took place. The precipitations between the different location can easily differ showing, incidentally, that the spatial spatial distribution of rain is a key factor.

\subsection{Ground measurements versus $10 \times 10 \mathrm{~km}^{2}$ soil moisture}

In order to address the uncertainties associated with the spatial averaging, comparison between point like and $10 \times 10 \mathrm{~km}^{2}$ simulations against ground measurements are done (Fig. 6). The $10 \times 10 \mathrm{~km}^{2}$ area used is the one covering both Melbex 1 and Melbex 2 campaigns. The point like and $10 \times 10 \mathrm{~km}^{2}$ soil moisture data are extracted within Melbex 1 

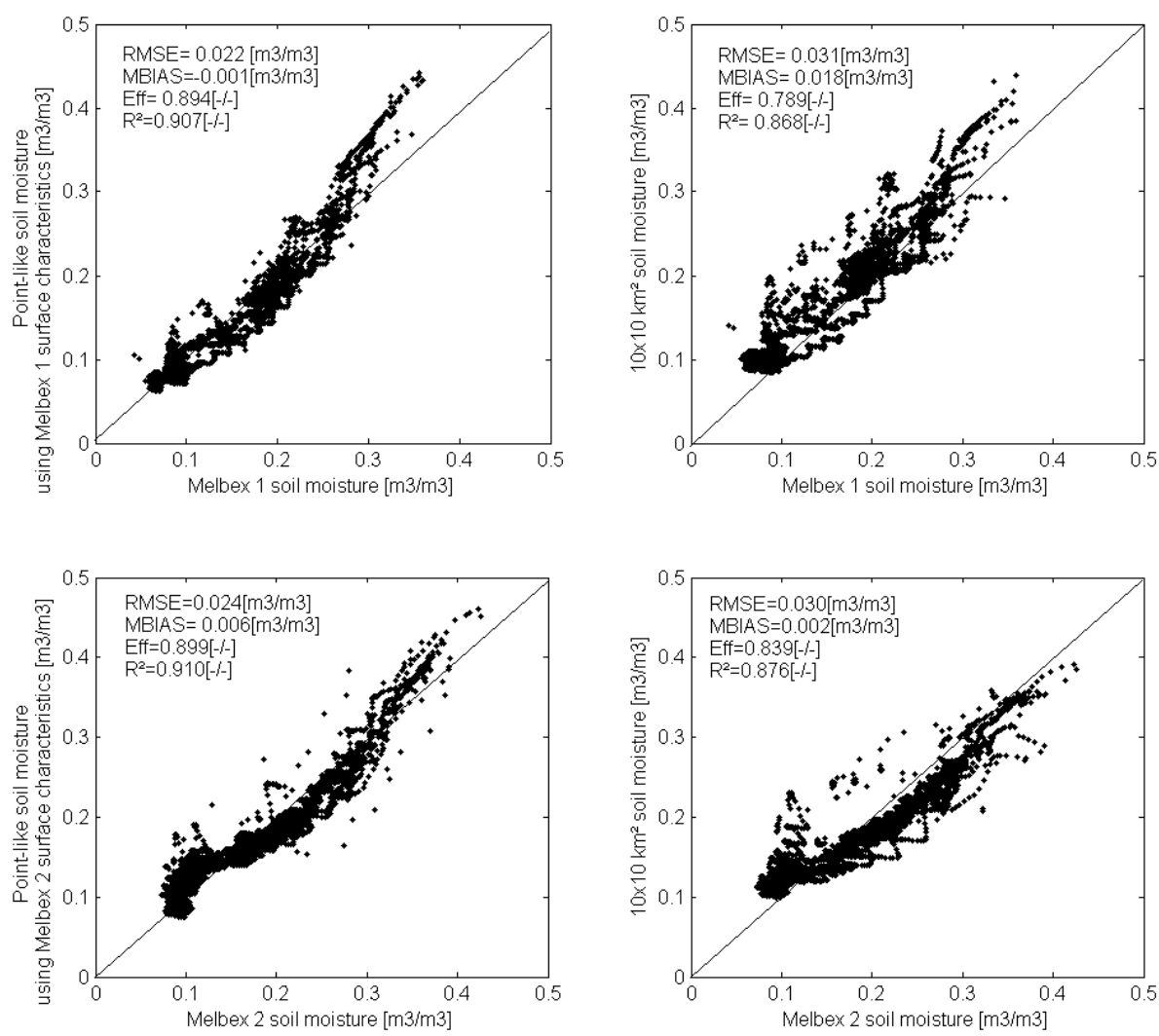

Fig. 6. Comparison between point like (left side) and $10 \times 10 \mathrm{~km}^{2}$ simulations (right side) against ground measurements from Melbex 1 (up side) and Melbex 2 (down side) campaigns. The $10 \times 10 \mathrm{~km}^{2}$ area is the one covering both Melbex 1 and Melbex 2 campaigns and data are extracted to correspond to both campaign periods.

or Melbex 2 period. When comparing in situ soil moisture with $10 \times 10 \mathrm{~km}^{2}$ simulations, similar results are observed. All the scores obtained are in the required range (less than $0.04 \mathrm{~m}^{3} / \mathrm{m}^{3}$ ). A slight overestimation of soil moisture within hight values is observed in all cases. This may be due to the volumetric water content at saturation which gives after calibration higher values than the recorded ones (see Sect. 4.1.1).

Using the SVAT for the spatialization as well as a linear interpolation method we can obtain for instance a soil moisture map over the entire $50 \times 50 \mathrm{~km}^{2}$ like in Fig. 7. The map represents the averaged soil moisture from January until the end of April 2005. A representation of soil moisture heterogeneity within the $50 \times 50 \mathrm{~km}^{2}$ is showed, with two marked zones of drier soil moisture. For this case a mean soil moisture value of $0.164 \mathrm{~m}^{3} / \mathrm{m}^{3}$ is obtained.

\subsection{Comparison with remote sensing data}

\subsubsection{Comparison with AMSR-E data}

A comparison between spatialized soil moisture and the AMSR-E soil moisture product (Njoku L3) is made. The simulated soil moisture as well as the AMSR-E soil moisture product used are representative for the $50 \times 50 \mathrm{~km}^{2}$ area. The penetration depth of AMSR-E sensor is considered to be $2 \mathrm{~cm}$ so the soil moisture for the first two simulated layers is considered. The comparison is done from 2005 to 2007 . Here are presented results from 2005 as the same evolution is observed for the other years. In a first step, the absolute values of the AMSR-E soil moisture product are compared with the simulated spatialized data. A severe lack of soil moisture dynamics and also a big difference between the absolute value of the two dataset are observed (RMSE $=0.066 \mathrm{~m}^{3} / \mathrm{m}^{3}$, MBIAS $\left.=0.015 \mathrm{~m}^{3} / \mathrm{m}^{3}, R^{2}=0.051-/-\right)$. Because of the different soil moisture dynamics and biases, it is difficult to compare the various datasets in detail. Consequently, all next comparison are undertaken with normalized data, leading to the loss of the absolute aspects. 


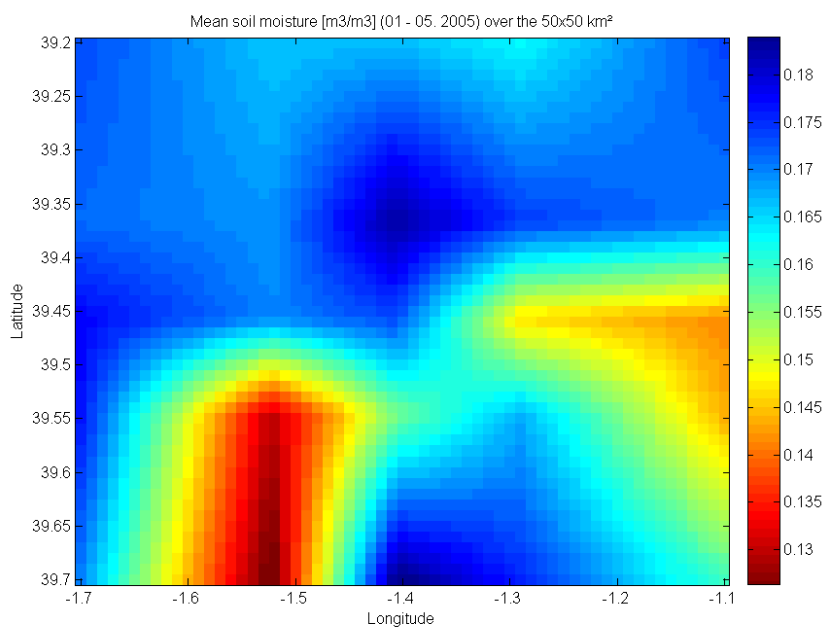

Fig. 7. Distributed soil moisture over the VAS $50 \times 50 \mathrm{~km}^{2}$ area. Data represents the mean of soil moisture from 1 January to 30 April 2005.

The results of this normalization can be seen in Fig. 8 . The dynamics of the soil moisture are very well captured at the beginning and also at the end of the year, from January to March we observed an RMSE $=0.146-/$ $\left(R^{2}=0.470-/-\right.$, MBIAS $=-0.100-/-$, Eff $\left.=-0.610-/-\right)$ and at the end of the year, from October to December RMSE $=0.150-/-$ $\left(R^{2}=0.444-/-\right.$, MBIAS=0.041-/-, Eff=0.207-/- $)$. In the winter season, the signal of AMSR-E soil moisture shows a small difference when compared to the spatialized soil moisture. This may be explained by the sensitivity of the microwave signal to soil freezing and by the reduced dynamics of the surface soil moisture during winter. In the middle of the year, from April to September, the opposite trend is observed between both datasets. From April to September no correlation is observed $\left(R^{2}=0.150-/-\right)$ and the RMSE is twice that of the rest of the year (0.348-/-). The inversion algorithm for the AMSR-E soil moisture uses the $10.7 \mathrm{GHz}$ and $18.7 \mathrm{GHz}$ brightness temperature data (Njoku et al., 2003). The increased attenuation by vegetation and the superficial sensing depth (on the order of $1 \mathrm{~cm}$ for bare soil) for higher frequencies is a limit in the soil moisture retrieval from AMSRE data. This can be seen by plotting the leaf area index (MODIS) corresponding to the site. When the growing season begins, the AMSR-E signal follows the vegetation signal (Fig. 8).

The polarization ratio provides a better agreement (than the soil moisture product from AMSR-E) with simulated soil moisture even in the vegetation growing period. This is shown by the scores obtained: at the beginning of the year, from January to March we observed an RMSE $=0.165$ /- $\left(R^{2}=0.655-/-\right.$, MBIAS $=-0.142-/-$, Eff $\left.=-0.872-/-\right)$, at the end of the year, from October to December RMSE $=0.163$ /- $\left(R^{2}=0.604-/-\right.$, MBIAS $\left.=-0.115-/-, \quad \mathrm{Eff}=-0.116-/-\right)$ and in the middle of the year, from April to September $R^{2}=0.466-/-$

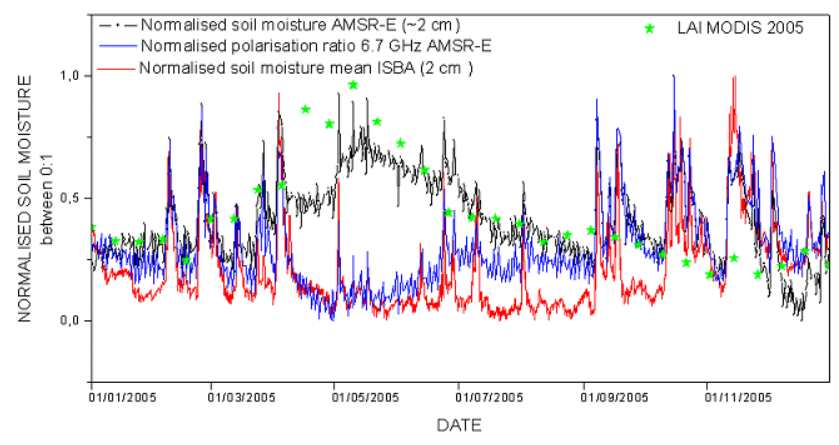

Fig. 8. Comparison between surface soil moisture AMSR-E (black line), spatialized soil moisture from ISBA (red line) and the polarization ratio at $6.9 \mathrm{GHz}$ AMSR-E (blue line). The soil moisture data are representative over $2 \mathrm{~cm}$ depth. All values are normalized between $(0,1)$. The leaf area index from MODIS is also represented here (green stars).

and the RMSE $=0.206-/-($ MBIAS $=-0.178-/-, \quad E f f=-1.402-$ /-). If the entire year is considered, better scores are obtained: RMSE $=0.186-/-, R^{2}=0.627-/-$, MBIAS $=-0.153-/-$, $\mathrm{Eff}=-0.553-/$. It shows that its dynamics is well correlated to the soil moisture variations.

\subsubsection{Comparison with ERS-SCAT data}

A comparison is also performed between spatialized soil moisture and the ERS-SCAT soil wetness product (Wagner SSM). The derived product represents the relative wetness of the first centimeters between totally dry conditions $(0 \%)$ and total water capacity $(100 \%)$.

In order to compare the two data sets, the absolute values of the simulated soil moisture are normalized between $(0,1)$. The penetration depth of ERS-SCAT sensor is considered to be at about $2 \mathrm{~cm}$ so the mean of the first two simulated layers from ISBA is considered. Figure 9 presents the comparison between simulated and observed surface soil moisture during a one year period. At the beginning of the year, from January to end of March RMSE $=0.195-/-, R^{2}=0.339$ $/-$, MBIAS $=-0.085-/-$, Eff $=-0.472-/-$ and at the end of the year, from the end of September to December RMSE $=0.149$ $/-, R^{2}=0.330-/-$, MBIAS=0.036-/-, Eff $=-0.735-/-$. An underestimation of the soil moisture level by the ERS-SCAT product is observed. In the middle of the year, from April to September $\left(R^{2}=0.222-/-\right.$, RMSE $=0.206-/-$, MBIAS $=0.102-/-$ , Eff $=-1.014-/-)$, as for the AMSR-E soil moisture product, the vegetation influence the ERS-SCAT signal. This leads to an overestimation of the soil moisture estimates during the vegetation growing period.

For 2005 only 45 observations are available over the $50 \times 50 \mathrm{~km}^{2}$ area. This is a limit in completely understanding the soil moisture variability. A frequent revisit time is important for hydrologic applications, especially to obtain 


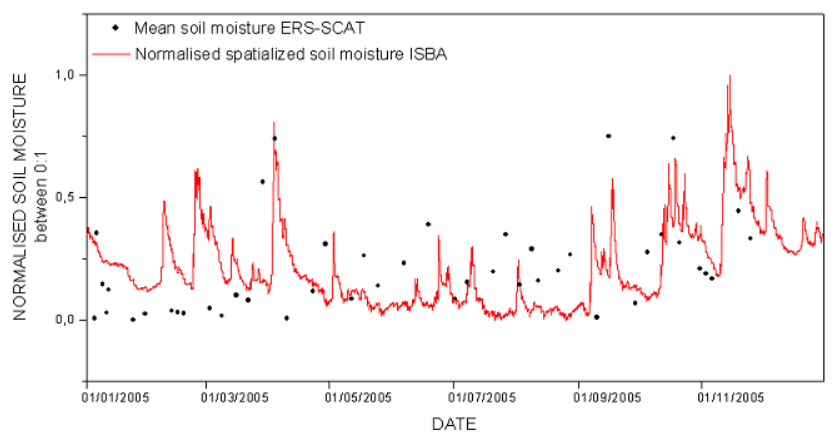

Fig. 9. Comparison between surface soil moisture ERS-SCAT (black stars) and spatialized soil moisture mean from ISBA (red line). The soil moisture data are representative over $2 \mathrm{~cm}$ depth.

adequate sampling of surface wetting and drying between precipitation events.

\section{Conclusions}

In the framework of ESA's Soil Moisture and Ocean Salinity (SMOS) mission, this paper investigates the ability to reproduce the high temporal and spatial heterogeneity of soil moisture fields at SMOS pixel scale. This is the first step in the process of Calibration and Validation (Cal/Val) activities of the SMOS data. The study was performed for 2004-2008 over the Valencia Anchor Station (VAS), which was selected to be one of the main key test sites for the SMOS Cal/Val activities. In this purpose, in situ measurement including two main campaigns (Melbex 1 and Melbex 2), detailed knowledge of the environment (land use, texture) and meteorological stations are used to describe VAS. The hydrological process as well as the spatialization of the soil moisture fields are performed by the use of the SVAT model, SURFEX (Externalized Surface) - module ISBA (Interactions between Soil-Biosphere-Atmosphere) from Météo-France. In order to minimize the error with respect to SMOS mission requirements, both the calibration and the validation of the SVAT model were done using in situ soil moisture data from two campaigns: Melbex 1 and Melbex 2. Based on local atmospheric and surface observations from Valencia Anchor Station, it was found that the calibrated ISBA was able to faithfully reproduce the hydrological processes at the surface level. The RMSE decreases from $0.042 \mathrm{~m}^{3} / \mathrm{m}^{3}$ when using the default ISBA to $0.022 \mathrm{~m}^{3} / \mathrm{m}^{3}$ using the calibrated version. A new database for soil hydraulic parameters was established so as to improve the soil moisture simulations. The new parametrization was validated by the use of other dataset of soil moisture ground measurements recorded during Melbex 2 campaing. The value of $0.024 \mathrm{~m}^{3} / \mathrm{m}^{3}$ obtained for the RMSE when comparing the simulated soil moisture with data from Melbex II campaign is adequate for assessing the SMOS validation with an accuracy better than $0.04 \mathrm{~m}^{3} / \mathrm{m}^{3}$. A comparison between point like and $10 \times 10 \mathrm{~km}^{2}$ simulations against ground measurements was also done to address the issue related to the spatial averaging. A slight overestimation of soil moisture is observed at high values but the scores obtained are within the required range (less than $0.04 \mathrm{~m}^{3} / \mathrm{m}^{3}$ ).

The validation of soil moisture remote sensing products is an important issue and in most cases until now, papers describe how to associate point/network measurement to remote sensing products. None of these studies characterize the entire pixel as viewed by a satellite. The detailed knowledge of the area as well as the use of a interpolation method for the distribution of the atmospheric forcing allowed the obtaining of a spatial distribution of the soil moisture fields over the $50 \times 50 \mathrm{~km}^{2}$ area.

Comparisons of this spatialized soil moisture with three kinds of remote sensing information is done in order to test the approach. AMSR-E's soil moisture and polarization ratio as well as ERS-SCAT soil moisture products are used in this study. The penetration depth and the re-sampling grid of the soil moisture products used for each satellite are also considered. Although AMSR-E surface soil moisture product is not able to capture the absolute value, it provides reliable information on surface soil moisture temporal variability, at seasonal and rainy events scale. In the middle of the year, from April to September, the vegetation has an important influence on the measured signal. During the growing season the AMSR-E signal is very perturbed. The polarization ratio $6.9 \mathrm{GHz}$ provides a better agreement with simulated soil moisture even in the vegetation growing period. A comparison is done between spatialized soil moisture and the ERSSCAT soil moisture product (Wagner SSM). In this case also the seasons are well marked but the lack of a higher temporal resolution (45 observations were available over the area for 2005) prevented capturing the soil moisture variability over the VAS area.

Radiometer signals received in $\mathrm{L}$ and $\mathrm{C}$ band are susceptible to man-made radio frequency interferences (Le Vine and Haken, 2003; Njoku et al., 2005). SMOS, now launched, has detected a significant amount of RFI sources over the globe. Among these RFI sources, some of them are over Spain, affecting also the VAS test site. The Spanish authorities concentrate their efforts and managed already to stop most of these sources. The actual brightness temperature values over VAS are within the range of expected values. As the soil moisture simulation process is now validated, future works will imply simulating the SMOS brightness temperature as part of the $\mathrm{Cal} / \mathrm{Val}$ activities.

Acknowledgements. The authors wish to thank the European Space Agency (ESA), the Centre National d'Etudes Spatiales (CNES), the Centre National de la Recherche Scientifique - Institut National des Sciences de l'Univers (CNRS- INSU SIC) and the French National Programme TOSCA (Terre, Océans, Surfaces Continentales et Atmosphére) for supporting this work. We also wish to thank the NASA National Snow and Ice Data Center (NSIDC) for providing AMSR-E data as well as the Institute for Photogrammetry and 
Remote Sensing, Vienna University of Technology, Vienna, Austria for providing the ERS-SCAT data. We thank also the Centre national de Recherches Météorologiques and Jean Christophe Calvet (CNRM) - Météo-France for the SURFEX model. The authors wish to thank also the Spanish Agency for Meteorology (AEMet) and to the Jucar River Basin Authority (CHJ) for the meteorological data.

Edited by: N. Verhoest

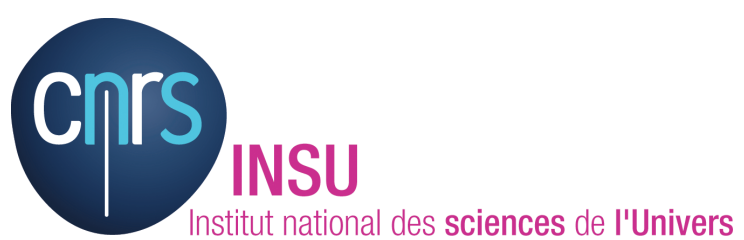

The publication of this article is financed by CNRS-INSU.

\section{References}

Albergel, C., Rüdiger, C., Carrer, D., Calvet, J.-C., Fritz, N., Naeimi, V., Bartalis, Z., and Hasenauer, S.: An evaluation of ASCAT surface soil moisture products with in-situ observations in Southwestern France, Hydrol. Earth Syst. Sci., 13, 115-124, doi:10.5194/hess-13-115-2009, 2009.

Betts, A., Ball, J., Beljaars, A., Miller, M., and Viterbo, P.: The land surface-atmosphere interaction : A review based on observational and global modeling perspectives, J. Geophys. Res., 101(D3), 7209-7225, 1996.

Boone, A.: Modelisation des processus hydrologiques dans le schema de surface ISBA: Inclusion d'un reservoir hydrologique, $\mathrm{du}$ gel et modelisation de la neige, $\mathrm{PhD}$ thesis, University Paul Sabatier, Toulouse, France, 252 pp., 2000.

Boone, A., Calvet, J.-C., and Noilhan, J.: The inclusion of a third soil layer in a Land Surface Scheme using the Force-Restore method, J. Appl. Meteorol., 38, 1611-1630, 1999.

Boone, A., Masson, V., Meyers, T., and Noilhan, J.: The influence of the inclusion of soil freezing on simulations by a soilvegetation-atmosphere transfer scheme, J. Appl. Meteorol., 39, 1544-1569, 2000.

Bosch, D. D., Lakshmi, V., Jackson, T. J., Choi, M., and Jacobs, J. M.: Large scale measurements of soil moisture for validation of remotely sensed data: Georgia soil moisture experiment of 2003, J. Hydrol., 323, 120-137, 2006.

Braud, I., Noilhan, J., Bessemoulin, P., Mascart, P., Havercamp, R., and Vauclin, M.: Bareground surface heat and water exchanges under dry conditions: Observations and parameterization., Bound.-Lay. Meteorol., 66, 173-200, 1993.

Brooks, R. H. and Corey, A. T.: Properties of porous media affecting fluid flow, J. Irrig. Drain. E.-ASCE, IR 2, 61-88, 1966.

Brutsaert, W. H.: On a derivable formula for long-wave radiation from clear skies, Water Resour. Res., 11(2), 742-744, 1975.

Calvet, J.-C., Noilhan, J., and Bessemoulin, P.: Retriving the rootzone soil moisture from surface soil moisture or temperature estimates : a feasibility study based on field measurements, J. Appl. Meteorol., 37, 371-386, 1998.
Cano, A., Millan-Scheiding, C., Wigneron, J.-P., Antolin, C., Balling, J., Grant, J., Kruszewski, A., Saleh, K., Sobjaerg, S., Skou, N., and Lopez-Baeza, E.: The Mediterranean Ecosystem L-Band EXperiment over vineyards (Melbex-2), 10th Specialist Meeting on Microwave Radiometry and Remote Sensing for the Environment, Italy, 2008.

Cano, A., Saleh, K., Wigneron, J. P., Antolín, C., Balling, J., Kerr, Y. H., Kruszewski, A., Millán-Scheiding, C., Søbjaerg, S. S., Skou, N., and López-Baeza, E.: The SMOS Medierranean Ecosystem L-band experiment (Melbex-1) over natural shrubs, Remote Sens. Environ., 114(4), 844-853, doi:10.1016/j.rse.2009.11.019, 2010.

Clapp, R. B. and Hornberger, G. M.: Empirical Equation for some soil hydraulic properties, Water Resour. Res., 14, 601-604, 1978.

Cosby, B. J., Hornberger, G. M., Clapp, R. B., and Ginn, T. R.: A Statistical exploration of the relationships of soil moisture characteristics to the physical properties of soils, Water Resour. Res., 20, 682-690, 1984.

Draper, C., Walker, J., Steinle, P., de Jeu, R., and Holmes, T.: An evaluation of AMSR-E derived soil moisture over Australia., Remote Sens. Environ., 113(4), 703-710, 2009.

Delwart, S., Bouzinac, C., and Wursteisen, P.: Overall SMOS Cal/Val Plan and Requirements, SMOS 7th workshop, Esrin, 2007.

Entekhabi, D. and Rodrigues-Iturbe, I.: An analytic framework for the characterization of the space-time variability of soil moisture, Adv. Water Res., 17(1-2), 35-45, 1994.

Entekhabi, D., Rodrigues-IturbeNakamura, I., and Castelli, F.: Mutual Interaction of Soil Moisture state and atmospheric processes, J. Hydrol., 183, 3-17, 1996.

Giordani, H.: Expériences de validation unidimensionnelles du schéma de surface NP89 aux normes Arpége sur trois sites de la campagne EFEDA 91, Note de travail 24 GMME/Météo-France, 1993.

Gruhier, C., de Rosnay, P., Kerr, Y. H., Mougin, E., Ceschia, E., Calvet, J.-C., and Richaume, P.: Evaluation of AMSR-E soil moisture product based on ground measurements over temperate and semi-arid regions, Geophys. Res. Lett., 35, L10405, doi:10.1029/2008GL0333330, 2008.

Gruhier, C., de Rosnay, P., Hasenauer, S., Holmes, T., de Jeu, R., Kerr, Y., Mougin, E., Njoku, E., Timouk, F., Wagner, W., and Zribi, M.: Soil moisture active and passive microwave products: intercomparison and evaluation over a Sahelian site, Hydrol. Earth Syst. Sci., 14, 141-156, doi:10.5194/hess-14-1412010, 2010.

Jackson, T. J., LeVine, D., Swift, C., Schmugge, T. J., and Schiebe, F.: Large area mapping of soil moisture using the ESTAR passive microwave radiometer, Remote Sens. Environ., 54(1), 2737, 1995.

Jackson, T. J., Le Vine, D. M., Hsu, A., Oldack, A., Starks, P., Swift, C., Isham, J., and Haken, M.: Soil moisture Mapping at regional scales using microwave radiometry: The southern great plains hydrology experiment, IEEE T. Geosci. Remote, 37(5), 2136-2151, 1999.

Jones, A., Vukićević, T., and Vonder Haar, T.: A microwave satellite observational operator for variational data assimilation of soil moisture, J. Hydrometeorol., 5, 213-229, 2004.

Kerr, Y. H.: Soil Moisture from space: Where we are?, Hydrogeol. J., 15, 117-120, 2007. 
Kerr, Y. H., Waldteufel, P., Wigneron, J.-P., Martinuzzi, J.-M., Font, J., and Berger, M.: Soil moisture retrieval from Space: The soil moisture and ocean salinity (SMOS) mission, IEEE T. Geosci. Remote, 39(8), 1729-1735, 2001.

Le Moigne, P., Boone, A., Calvet, J.-C., Decharme, B., Faroux, S., Gibelin, A.-L., Lebeaupin, C., Mahfouf, J.-F., Martin, E., Masson, V., Mironov, D., Noilhan, J., Tulet, P., and Van Den Hurk, B.: SURFEX scientific documentation, 2009.

Lopez-Baeza, E., Alonso, S., Comerón, A., Diaz-Pabon, R., Domenech, C., Gimeno-Ferrer, J., Jorge, J., Labajo, A., Pineda, N., Pino, D., Rius, A., Rocadenbosch, F., Saleh, K., Sicard, M., Tarruella, R., Torrobella, J., and Velazquez, A.: A High-Quality Dataset of Land-Surface and Atmospheric Measurements for the Comparison/Crosscalibration of Data From Large Scale Optical Earth Observation Sensors in Space, The Valencia Anchor Station, Proceedings of the Workshop on Inter-Comparison of Large Scale Optical and Infrared Sensors, ESA/ESTEC 12-14 October 2004, ESA-WPP-244, 2005a.

Lopez-Baeza, E., Antolin, M. C., Belda, F., Cano, A., Carbo, E., Crapeau, M., Fidalgo, A., Juglea, S., Kerr, Y., MillanScheiding, C., Rodriguez, D., Saleh, K., Wigneron, J.-P., and team: Validation of SMOS Products over Mediterranean Ecosystem Vegetation at the Valencia Anchor Station Reference Area, Experimental Plan SMOS Validation Rehearsal Campaign, SMOS Cal/Val AO I.D, 2008.

Le Vine, D. M. and Haken, M.: RFI at L-band in synthetic aperture radiometers, P. IEEE Int. Geosci. Remote Sens. Symposium, Toulouse, France, 3, 1742-1744, 2003.

Magagi, R. and Kerr, Y.: Retrieval of soil moisture and vegetation characteristics by use of ERS-1 wind scatterometer over arid and semi-arid areas, J. Hydrol., 188-189, 361-384, 1997.

Mahfouf, J.-F. and Noilhan, J.: Comparative study of various formulations of evaporation from bare soil using in situ data, J. Appl. Meteorol., 30, 351-362, 1991.

Masson, V., Champeaux, J.-L., Chauvin, F., Meriguet, C., and Lacaze, R.: A global database of land surface parameters at 1$\mathrm{km}$ resolution in meteorological and climate models, J. Climate, 16(9), 1261-1282, 2003.

Millan-Scheiding, C., Marco, J., Soriano, M., Torre, E., Torregrosa, G., Abalos, B., Requena, F., Cano, A., Antolin, C., and LopezBaeza, E.: VAS Soil and Vegetation Characterization, SMOS meeting in Bordeaux, INRA, 30-31 October, 2008.

Njoku, E. G., Ashcroft, P., Chan, T. K., and Li, L.: Global survey and statistics of radio-frequency interference in AMSR-E land observations, IEEE Geosci. Remote Sens. Lett., 43(5), 938-947, 2005.

Njoku, E. G.: AMSR-E/AQUA daily L3 surface soil moisture, interpretive parms, \& QC EASE-Grids, Boulder, CO, USA: National Snow and Ice Data Center, Digital Media, 2004.

Njoku, E. G. and Entekhabi, D.: Passive microwave remote sensing of soil moisture, J. Hydrol., 184, 101-129, 1996.
Njoku, E. G., Jackson, T., Lakshmi, V., Chan, T., and Nghiem, S.: Soil moisture retrieval from AMSR-E, IEEE Geosci. Remote Sens. Lett., 41(2), 215-229, 2003.

Noilhan, J. and Lacarrère, P.: GCM Grid-Scale Evaporation from Mesoscale Modeling, J. Climate., 8, 206-223, 1995.

Noilhan, J. and Mahfouf, J.-F.: The ISBA land surface parameterization scheme, Global Planet. Change, 13, 145-159, 1996.

Noilhan, J. and Planton, S.: A simple parameterization of land surface fluxes processes for meteorological models, Mon. Weather. Rev., 117, 536-549, 1989.

Pellarin, T., Laurent, J., Cappelaere, B., Decharme, B., Descroix, L., and Ramier, D.: Hydrological modelling and associated microwave emission of a semi-arid region in South-western Niger, J. Hydrol., 375(1-2), 262-272, doi:10.1016/j.jhydrol.2008.12.003, 2009.

Rüdiger, C., Calvet, J.-C., Gruhier, C., Holmes, T. R. H., de Jeu, R. A. M., and Wagner, W.: An Intercomparison of ERSSCAT and AMSR-E Soil Moisture Observations with Model Simulations over France, J. Hydrometeorol., 10(2), 431-447, doi:10.1175/2008JHM997.1, 2009.

Schmugge, T., Jackson, T., Kustas, T. J., and Schmugge, T., Jackson, T., Kustas, T. J., and Wang, J. R. : Passive microwave remote sensing of soil moisture: results from HAPEX, FIFE and MONSOON'90, ISPRS J. Photogramm., 47, 127-143, 1992.

Shao, Y. and Henderson-Sellers, A.: Validation of soil moisture simulation in land surface parameterisation schemes with HAPEX data, Global Planet. Change, 13, 11-46, 1996.

Shepard, D.: A two-dimensional interpolation function for irregularly-spaced data, Proceedings of the 1968 ACM National Conference, 517-524, 1968.

Wagner, W., Lemoine, G., and Rott, H.: A Method for Estimating Soil Moisture from ERS Scatterometer and Soil Data, IEEE T. Geosci. Remote, 70(2), 191-207, 1999a.

Wagner, W., Noll, J., Borgeaud, M., and Rott, H.: Monitoring soil moisture over the Canadian prairies with the ERS scatterometer, IEEE T. Geosci. Remote, 37, 206-216, 1999b.

Wagner, W., Blöschl, G., Pampaloni, P., Calvet, J.-C., Bizzarri, B., Wigneron, J.-P., and Kerr, Y.: Operational readiness of microwave remote sensing of soil moisture for hydrologic applications, Nord. Hydrol., 38(1), 1-20, 2006.

Wagner, W., Naeimi, V., Scipal, K., de Jeu, R., and MartínezFernández, J.: Soil moisture from operational meteorological satellites, Hydrogeol. J., 15(1), 121-131, doi:10.1007/s10040006-0104-6, 2007.

Wang, J. R., Shiue, J. C., Schmugge, T. J., and Engman, E. T.: The L-band PBMR measurements of surface soil moisture in FIFE, IEEE T. Geosci. Remote, 28, 906-914, 1990a.

Wigneron, J.-P., Calvet, J.-C., Pellarin, T., Van de Gried, A., Berger, M., and Ferrazzoli, P.: Retrieving near-surface soil moisture from microwave radiometric observations: current status and future plans, Remote Sens. Environ., 85(4), 489-506, 2003. 